\title{
Morphotectonic Analysis of Euphrates River Basin/ Iraq
}

\author{
Zeyad Jameel Al-Saedi ${ }^{\text {a }}$ \\ Mustafa Rashead Al-Obaidi ${ }^{\text {b }}$ \\ ${ }^{a, b}$ Geology department, College of science, University of Baghdad,Baghdad, Iraq \\ zeyadjameel@gmail.com_ mustafar_s@yahoo.com
}

Submission date:- 3/4/2018 Acceptance date:- 24/6/2018 Publication date:- 10/9/2018

Keywords: Morphotectonics, sub basin,Drainagedensity,Sinuosity,Hypsometric integral, Drainage basin asymmetry,Basin Shape, Transverse Topographic Symmetry, Active tectonic index .

\begin{abstract}
Morphological and morphotectonic analysis have been used to obtain information that influencebasins. Study area includes the Euphrates river basin in Iraq. Tectonically this area within Stable shelf,The Stable Shelf which covers the vast majority of focal south and west of Iraq reaches out into Syria and Jordan and Southwards into Kuwait and Saudi Arabia. It is separated in Iraq into three considerable structural zones. Discrimination of morphotectonic indices of Euphrates basin by using sevenindices. The Euphrates basin (main basin) was divided into four sub basin (s.b) Wadi Horan, Wadi Ubaiyidh, Shuab Hwaimy and Shuab Qusair.Which have been completed for each drainage basin utilizing remote sensing and GIS techniques. So as to identify tectonic activity, different indices including Drainage density (D), Sinuosity index (S), Hypsometric integral (HI), Drainage basin asymmetry (AF), Basin Shape (BS), Transverse Topographic Symmetry (T) and Active tectonic index (Iat). The study demonstrates that intensity of tectonic activities in different parts of the basin and sub basins are different. The values of Drainage density (D) main basin and sub basins are in high classes which mean that the study area has resultant of slight or impermeable subsurface material, little vegetation as well as a good discharge for water and sediments. The Sinuosity index (S) of all study area are sinuous and its semi equilibrium. Hypsometric integral (HI) of Horan, Ubaiyidh and shuab Hwaimy sub basins shows high values of $\mathrm{HI}$ which means high rates of geological erosion while the shuab Qusair and main basin shows moderate of erosion rates, HI high values shows that study area is tectonically uplifted. According to calculation of Drainage basin asymmetry (AF) the study area reflects inactive tectonic activity. The Basin Shape (BS) all of basins are in third class and it reflects inactive tectonic activity. After compute Transverse Topographic Symmetry (T) index in the area of investigate, the outcome demonstrate that all the sub basins lies in low active tectonics except wadi Horan and the main basin were moderate active tectonics. Based on Active tectonic index (Iat) all the basins were moderate active tectonics except Horan sub basin is active tectonically. These basins have evolved as a result of plate movements, subsidence, uplift and various erosional processes. The study shows variable relationship between faulting and valleys but most of the trends of faults are sub- parallel to Euphrates River. Faults orientations in the study area are parallel to NE-SW direction and NW-SE direction. And also the type of drainage network in study area which is varied from dendritic to parallel with SW-NE trending and its indicate that study area may be structurally control.
\end{abstract}

\section{Introduction}

The crash of the Arabian plate with the Iranian and Turkish plates continues to present day because the Red Sea divergent and the Arabian Plate Movement towards North and Northeast, which is in charge of the neotectonic and seismic events in the region (Al-Janabi, 1996). The area under investigate is part of the stable shelf, so its tectonic evolution was associated with the tectonic evolution of the stable shelf. The region was influenced by the pre-cambrian tectonic movements (Kibaran, Hajaz and Najd).These movements were affecting in the basement rocks appears of faults in the direction northeast-southwest, northwest- southeast. These faults have an essential role in the structural and structural development of the study area. Water resources of Iraq historically have depended largely on the surface water of the Tigris and the Euphrates Rivers since the Mesopotamian civilization. More than $75 \%$ of the available water of Iraq comes from outside the territory. Both the Tigris and the Euphrates are international rivers, their sources originating in Turkey. [1]. 
Euphrates River, The longest river in southwest Asia, it is one of the two main constituents of the Tigris-Euphrates river system. The river rises in Turkey and flows southeast across Syria and through Iraq. Formed by the confluence of the Karasu and Murat rivers in the Armenian Highland, the Euphrates descends between major ranges of the Taurus Mountains to the Syrian plateau. It then flows through western and central Iraq to unite with the Tigris River and continues, as Shatt Al-Arab, to the Arabian Gulf. The length of the Euphrates from the source of the Murat River to the confluence with the Tigris at 3,000 kilometers $(1,900 \mathrm{mi})$, of which 1,230 kilometers $(760 \mathrm{mi})$ is in Turkey, 710 kilometers $(440 \mathrm{mi})$ in Syria and 1,060 kilometers $(660 \mathrm{mi})$ in Iraq. In length of the Shatt al-Arab, which connects the Euphrates and the Tigris with the Gulf, is given by various sources as 145-195 kilometers (90-121 mi). Euphrates River is located between the Sedimentary Plain in the east and the Western desert of Iraq in the west. [2] Describes the Sedimentary Plain as a large sedimentary basin that represents a large syncline with active tectonic surface. This basin passes through a subsidence or depression, with small local elevation motions, which is associated with the Alpine movement of the mountains that occurred in the highlands Zagros, which is still active. So far, this basin receives the products of erosion and weathering of the mountainous area as the downward movement continues.

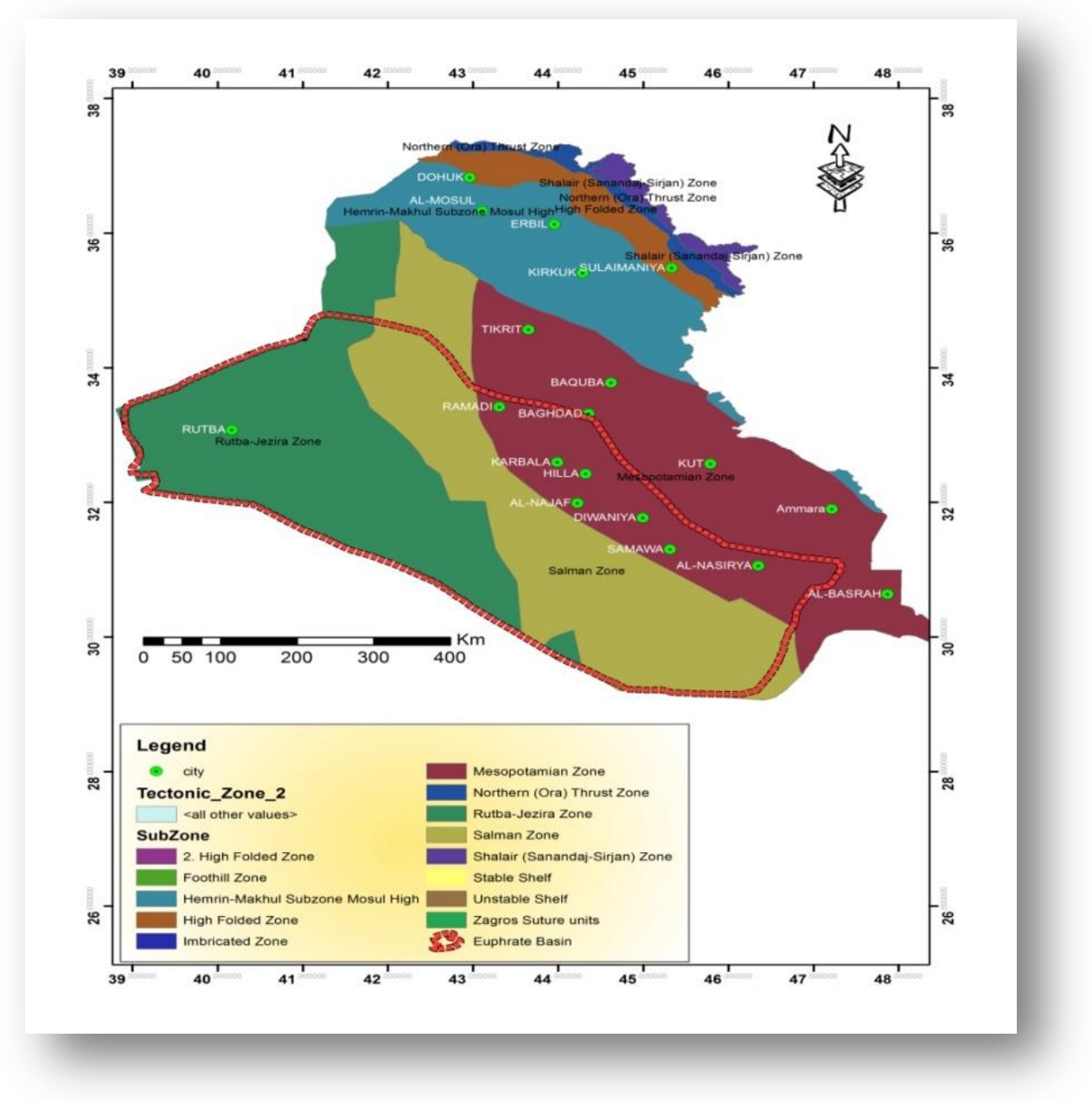

Figure (1) Tectonic partition of Iraq after [3]

\section{Location of area under investigate}

Study area includes the whole Euphrates river basin and it is represent the western and southern Iraqi desert. As in Fig (2). 


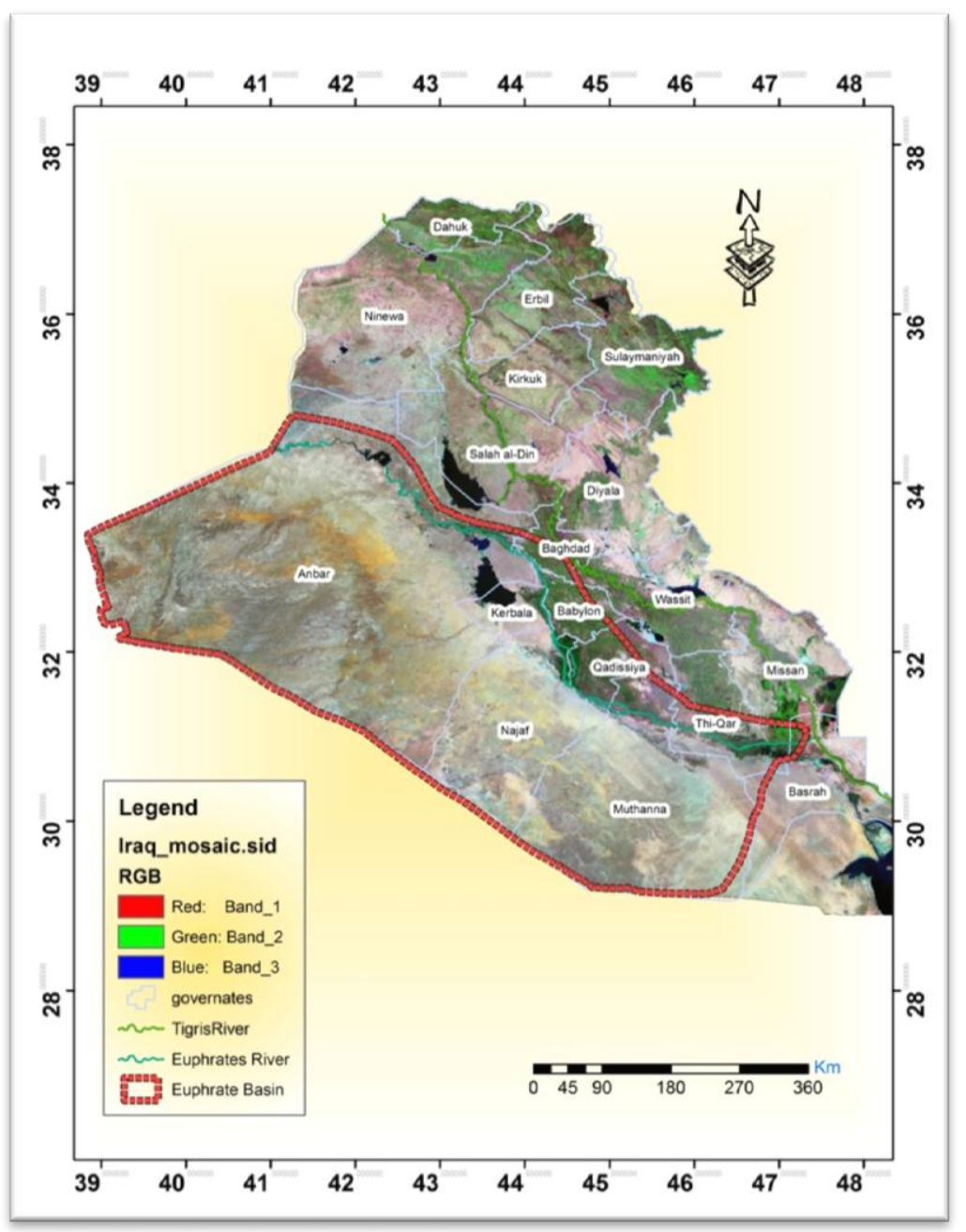

Figure (2) shows position of Euphrates basin

\section{Aim of study}

The principle point of present investigation is to compute different morphotectonics indices and relation between patterns with faults that affect Euphrates River basin.

\section{Methodology and Materials}

In this searchDigital Elevation Model (DEM) with $30 \mathrm{~m}$ resolution, geological map 1:1000000 are utilized to investigation and extraction of vigorousindicators and drainage networks. Arc GIs 10. Excel software's were utilized to get distinctive maps.. The methodology was done by following steps. 


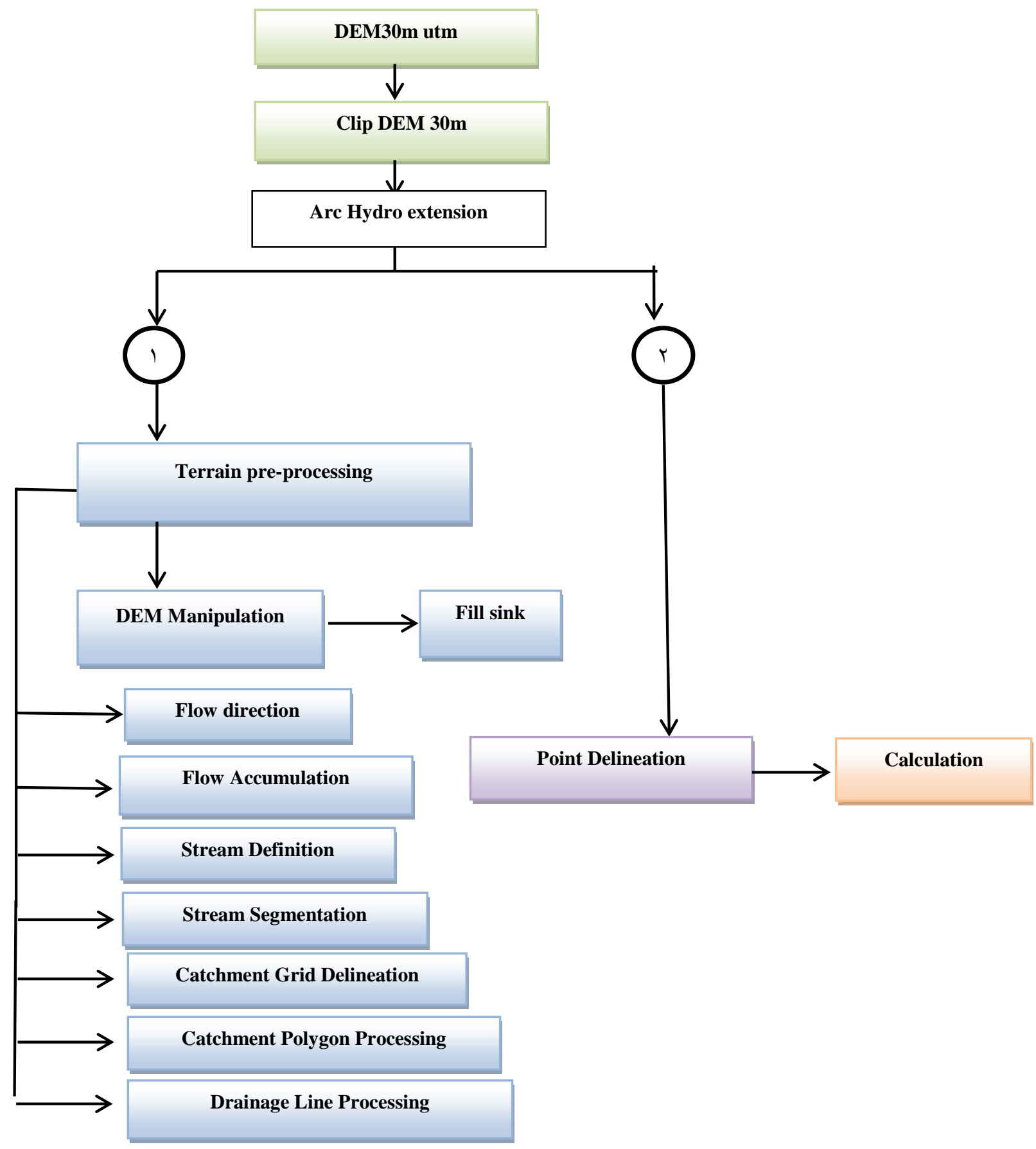

Figure (3) schematic Diagram of study 


\section{Morphotectonicsindices}

It has been known that the study area lies in Western and the Southern Deserts. There are no structural or physiographic boundaries between the two deserts, and the distinction is strictly geographic. [4].

Morphotectonic is the study of landforms created by tectonic processes. We implemented different indices including Drainage density (D), Sinuosity index (S), Hypsometric integral (HI), Drainage basin asymmetry (AF),Basin Shape (BS), Transverse Topographic Symmetry (T) and Active tectonic index (Iat). In this research, the Euphrates basin (main basin) was separated to four sub basin (s.b) which is adapted from the geological map scale 1:1000000, 1998.First: Wadi Horan, Second: Wadi Ubaiyidh, Third: Shuab Hwaimy and Shuab Qusair as in Fig(4).

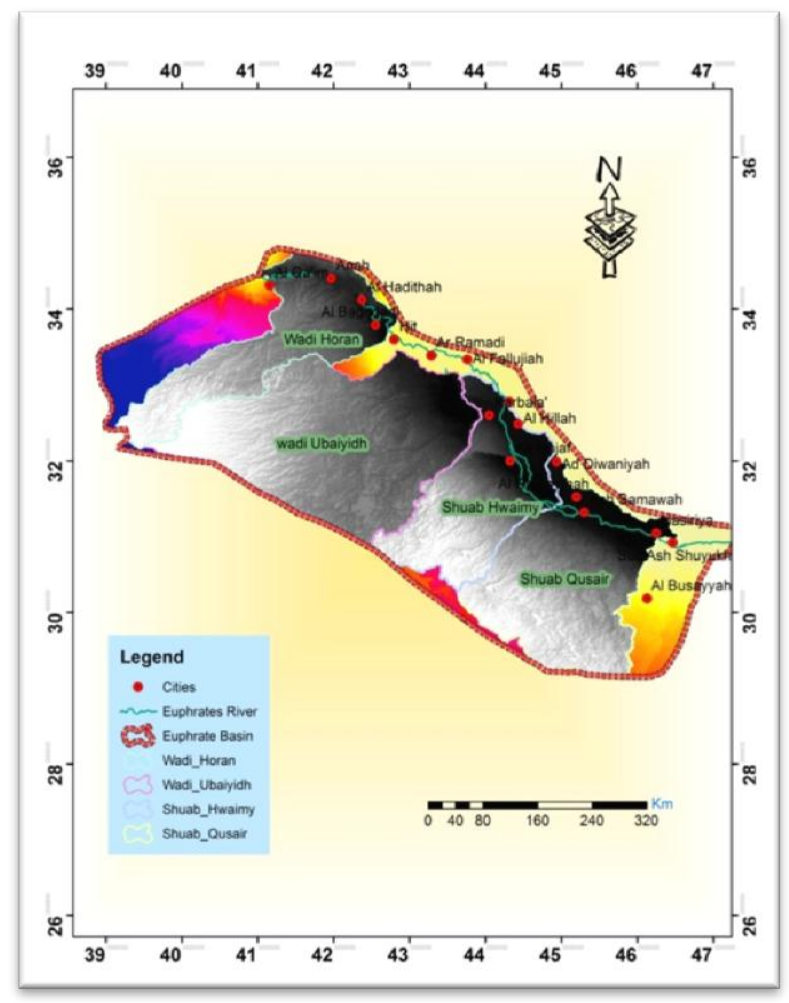

Figure (4) Shows the main $\&$ sub basin in study area

Some of indices were calculated by using geometry and measure tool in Arc GIS program such as (the basin area, basin length, basin perimeter, Maximum \& Minimum elevation, Form parameter whichis the ratio of Basin area (A) divided by (length of the Basin) ${ }^{2}$ and Percentage of the basins). As in table (1). 
Table (1) characteristics of main and sub basin representsAreas in $\mathrm{Km}^{2}$ and Length in $\mathrm{Km}$.

\begin{tabular}{|c|c|c|c|c|c|}
\hline $\begin{array}{c}\text { Sub basin } \\
\text { characteristics }\end{array}$ & $\begin{array}{c}\text { Wadi Horan } \\
\text { S.B }\end{array}$ & $\begin{array}{c}\text { WadiUbaiyidh } \\
\text { S.B }\end{array}$ & $\begin{array}{c}\text { ShuabHwaimy } \\
\text { S.B }\end{array}$ & $\begin{array}{c}\text { ShuabQusair } \\
\text { S.B }\end{array}$ & $\begin{array}{c}\text { Euphrates } \\
\text { Basin }\end{array}$ \\
\hline Basin Area Km ${ }^{2}$ & 32193 & 64947 & 32820 & 45744 & 232205 \\
\hline Basin Length Km & 370 & 272 & 193 & 253 & 793 \\
\hline Basin Width Km & 166 & 326 & 221 & 251 & 346 \\
\hline Basin Perimeter Km & 1814 & 2002 & 1155 & 1690 & 2240 \\
\hline Maximum elevation & 909 & 868 & 411 & 454 & 933 \\
\hline Minimum elevation & 58 & 31 & 14 & 2 & 1 \\
\hline Form & 0.2 & 0.8 & 0.8 & 0.7 & 0.3 \\
\hline Percentages of Basins & $13.8 \%$ & $27.9 \%$ & $14.1 \%$ & $19.7 \%$ & $\cdots$ \\
\hline
\end{tabular}

\subsection{Drainage Density index (D)}

The drainage density shows the closeness of distance of channels, hence giving a quantitative measure of the normal length of stream channel for the entire basin. High drainage density is the resultant of feeble or impermeable subsurface material, inadequate vegetation. Low drainage density prompts coarse seepage surface while high drainage density prompts fine waste surface. [5].

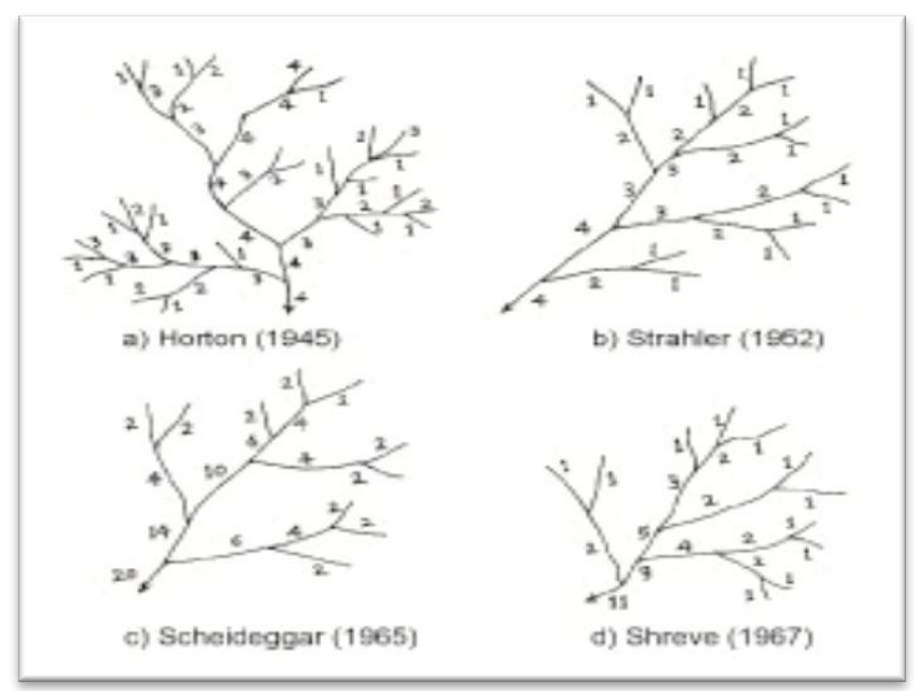

Figure (5) System of stream ordering

Ten stream orders were adapted in this study for main and sub basin, the length was calculated to each basin separately.As well as the Euphrates basin (main basin). 


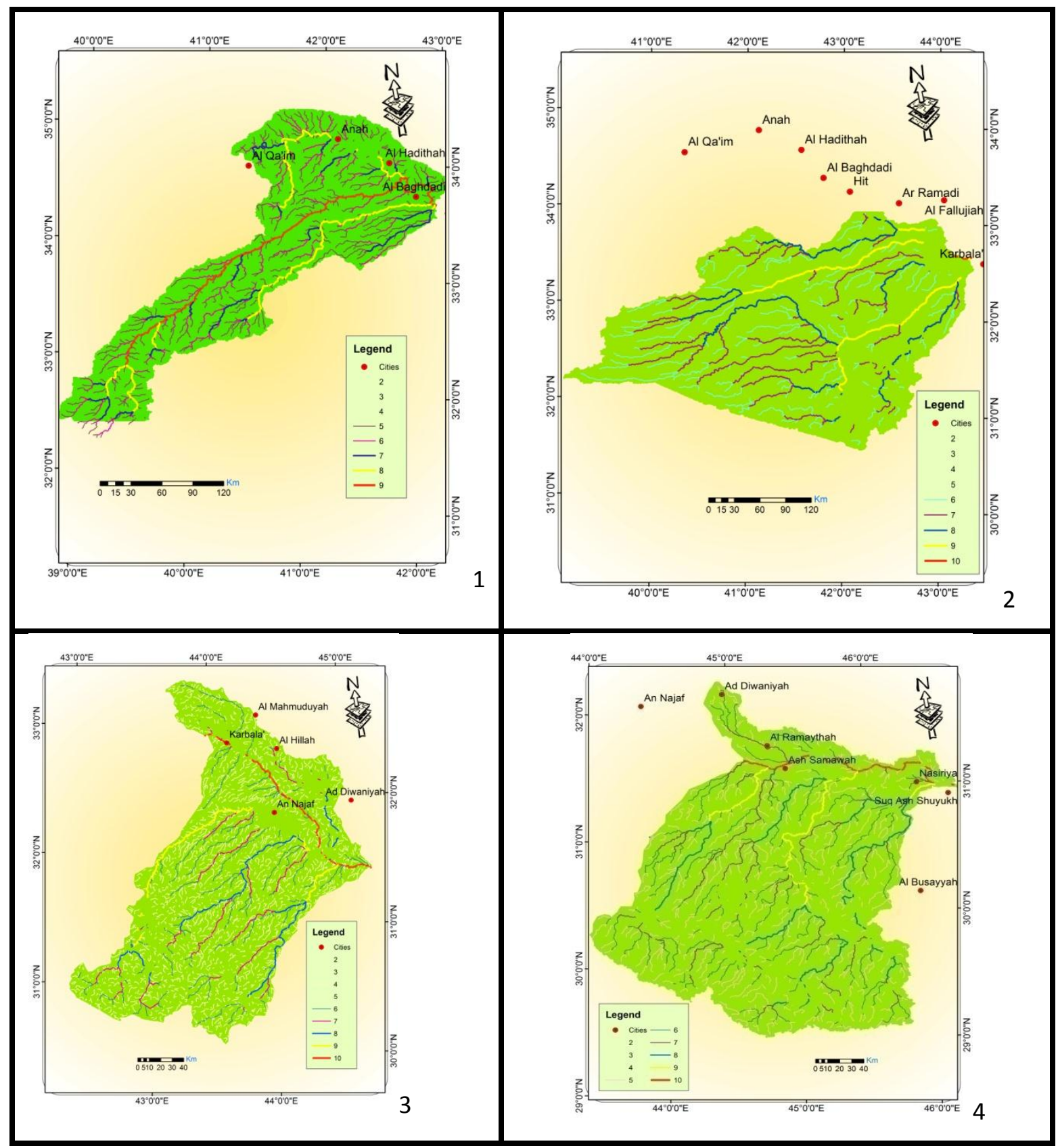

Figure (6) shows stream order in sub basins1-Wadi Horan, 2-Wadi Ubaiyidh,3-ShuabHwaimy and 4ShuabQusair respectively 


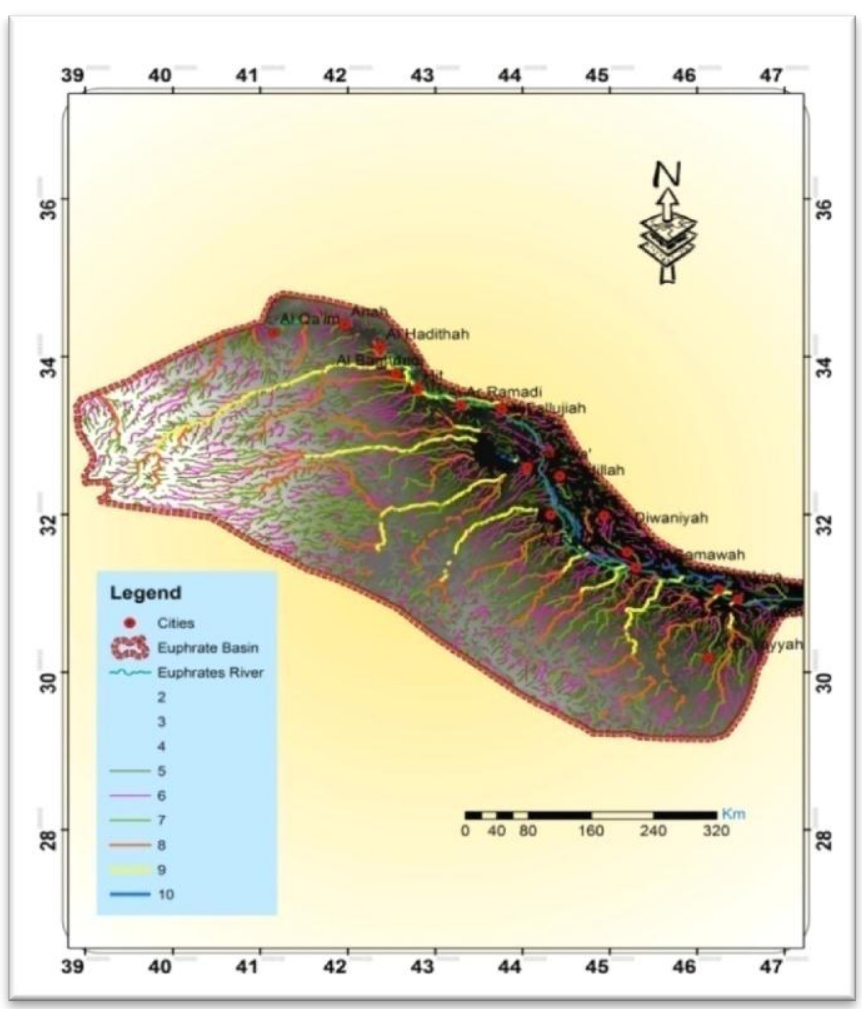

Figure (7) shows stream order in Euphrates basin

Drainage density is the proportion length of the stream to area of the region as below:

$$
\mathrm{D}=\mathrm{L} / \mathrm{A}
$$$$
1
$$

$D=$ Drainage density index

$L=$ total length of streams in $\mathrm{km}$

$A=$ total area in square kilometers

Low density is below0.6, average between 0.6 and 0.9 , high if it is above 0.9 [6]. Appling equation no.1 on table no. 1 we get the result as in table 2 .

Table (2). Values of Drainage density (D)

\begin{tabular}{|c|c|c|}
\hline Sub basin Name & Drainage Density & Class of D \\
\hline Wadi Horan & 1.8 & 3 High \\
\hline WadiUbaiyidh & 1.7 & 3High \\
\hline ShuabHwaimy & 1.7 & 3High \\
\hline ShuabQusair & 1.7 & 3High \\
\hline Main Basin & 1.7 & \\
\hline
\end{tabular}




\subsection{Sinuosity of River index $(S)$}

Sinuosity parameter isobtained by using the Equation. [7].

$$
\begin{aligned}
& \quad \mathrm{S}=\mathrm{C} / \mathrm{V} \ldots \ldots . . .2 \\
& S=\text { Sinusitis or the twists and turns of the river } \\
& C=\text { length of the river } \\
& V=\text { length of the valley }
\end{aligned}
$$

Rivers that have turns are near to be harmony, while the immediate river course speaks to more youthful and presence of neotectonic exercises in the territory. Rivers having a sinuosity of 1.5 are called sinuous, or more 1.5 are called meandering [8].Appling equation no.2 on table no. 1 we get the outcome as in table 3.

Table (3).Values of Sinuosity (S)

\begin{tabular}{|c|c|c|}
\hline Sub basin Name & Sinuosity & Class of S \\
\hline Wadi Horan & 1.33 & 1 sinuous \\
\hline WadiUbaiyidh & 1.05 & 1 sinuous \\
\hline ShuabHwaimy & 1.12 & 1 sinuous \\
\hline ShuabQusair & 1.31 & 1 sinuous \\
\hline Main Basin & 1.4 & 1 sinuous \\
\hline
\end{tabular}

\subsection{Hypsometric integral (HI)}

The hypsometry may reflects the interaction between tectonic and level of non stability in the balance of erosion, beside it could provide a valuable geomorphic index that constrains the relative importance of these processes, In general, land areas with higher rates of tectonic uplift have higher HI values as basins are less concave, and land areas that have been subject to net long-term erosion have lower HI values and basins are less convex. [9]. And it calculated by equation:

$\mathrm{HI}=($ mean elevation - Min.elev) / (Max.elev - Min.elev) -----3

Classified this parameterinto three categories: 1) $\mathrm{Hi} \geq 0.5,2) 0.4 \leq \mathrm{Hi}<0.5$, and 3) $\mathrm{Hi}<0.4$. [10].Appling equation no. 3 on table no. 1 we get the result as in table 4 .

Table (4). Amounts of Hypsometric index (HI)

\begin{tabular}{|c|c|c|}
\hline Sub basin Name & Hypsometric integral & Class of HI \\
\hline Wadi Horan & 0.5 & 1 \\
\hline WadiUbaiyidh & 1.03 & 1 \\
\hline ShuabHwaimy & 0.5 & 2 \\
\hline ShuabQusair & 0.4 & 2 \\
\hline Main Basin & 0.4 & 1 \\
\hline
\end{tabular}




\subsection{Drainage Basin Asymmetry Index (AF)}

Asymmetry index for determining the tectonic tilting of the drainage basins and larger areas are as follows in Equation

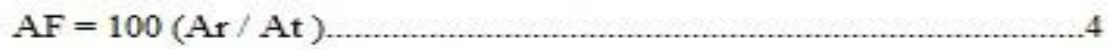

Ar: right area of the river, $A r$ : total area of the drainage basin.

Af $-50<7$ inactive, $15>$ Af $-50>7$ semi-active and Af-50 $>15$ is placed in active elass.

The parameter is critical to change in slop perpendicular to the heading of basin. An AFfactor above or underneath 50 may because from basin tilting, coming about either from active tectonics or lithologic structural dominate. To evaluate the relative active tectonics, the vital difference is what is important, and values of AF-50 range estimate 1 to 28. [10]. AF-50 $<7$ not vigorous, $15>\mathrm{AF}-50>7$ semi-vigorousand AF-50 $>15$ is placed in vigorous class. [11].Appling equation no.4 on table no.1 we get the result as in table 4.

Table (4). Values of Drainage basin asymmetry (AF)

\begin{tabular}{|c|c|c|}
\hline Sub basin Name & Drainage Basin Asymmetry AF & Class of AF \\
\hline Wadi Horan & 2.95 & 1 inactive \\
\hline WadiUbaiyidh & 2.96 & 1 inactive \\
\hline ShuabHwaimy & 2.46 & 1 inactive \\
\hline ShuabQusair & 2.99 & 1 inactive \\
\hline Main Basin & 0.72 & 1 inactive \\
\hline
\end{tabular}

\subsection{Basin Shape Index (BS)}

Also called "Elongation Ratio" it describes the horizontal projection of a basin, and it classified into three classes: 1) ( $\mathrm{BS} \geq 4)$ vigorous, 2$)(3 \leq \mathrm{BS}<4)$ semi-vigorous and 3$)(\mathrm{BS} \leq 3)$ not vigorous. [10]. It is defined as in equation:

$$
\mathrm{BS}=\mathrm{B} 1 / \mathrm{Bw} \text {------------------- } 5
$$

B1: is the length of a basin estimated from elevated point.

Bw: is the width of a basin estimated at its extensive point.

Appling equation no.5 on table no. 1 we get the result as in table 5 .

Table (5). Values of Basin shape (BS)

\begin{tabular}{|c|c|c|}
\hline Sub basin Name & Basin Shape BS & Class of BS \\
\hline Wadi Horan & 2.22 & 3 inactive \\
\hline WadiUbaiyidh & 0.83 & 3 inactive \\
\hline ShuabHwaimy & 0.87 & 3 inactive \\
\hline ShuabQusair & 1.0 & 3 inactive \\
\hline Main Basin & 2.29 & 3 inactive \\
\hline
\end{tabular}




\subsection{Transverse Topographic Symmetry Factor $(T)$}

Index $\mathrm{T}$ is a vector with a certain orientation and different values between $0-1$. In perfectly symmetrical Basins, the value of this index is zero. By reducing the symmetry of the busin, $T$ index increases and gets closer to 1 which is computed by Equation (6):

$$
\mathrm{T}=\mathrm{Da} / \mathrm{Dd}
$$

$D a=$ the distance between Midfielder of drainage basin and main river route

$D d=$ the distance between Midfielder of drainage basin and Water dividing line

Regards to present search, we were indicate class 1 for $\mathrm{T}>0.4$ high, class 2 for $\mathrm{T}$ between 0.2 and 0.4 moderate and class 3 for $\mathrm{T}<0.2$ low.[12].Appling equation no. 6 on table no. 1 we get the result as in table 6 .

Table (6) Values of Transverse topographic symmetry (T)

\begin{tabular}{|c|c|c|}
\hline Sub basin Name & Transverse Topographic Symmetry & Class of T \\
\hline Wadi Horan & 0.3 & 2moderate \\
\hline WadiUbaiyidh & 0.09 & 3low \\
\hline ShuabHwaimy & 0.1 & 3low \\
\hline ShuabQusair & 0.1 & 3low \\
\hline Main Basin & 0.4 & 2moderate \\
\hline
\end{tabular}

\subsection{Active Tectonics Index (Iat)}

After calculating the geomorphic indices in the study area is estimated tectonic activities in the area using Iat index. Iat index is achieved from the average of different geomorphic indicator classes according to the following equation:

$$
\text { Iat }=\mathrm{S} / \mathrm{N}
$$

$S$ : Total classes geomorphic indicators that is calculated

$N$ : Number of indicators

The values of the index were divided into four classes to define the degree of active tectonics: 1 -very high (1.0 $\leq$ Iatb1.5); 2 - high ( $1.5 \leq$ latb2.0); 3 -moderate ( $2.0 \leq$ Iatb2.5); and 4-kow (2.5 $\leq$ Iat)

[10]. Appling equation no.7 on indices we get the result as in table (7).

Table (7).Amounts of Active tectonic index (Iat)

\begin{tabular}{|c|c|c|c|c|c|c|c|c|c|}
\hline Sub basin & Class & Class & Class & Class & Class & Class & Value & Class & Tectonic \\
I & $\mathrm{S}$ & $\mathrm{HI}$ & $\mathrm{AF}$ & $\mathrm{BS}$ & $\begin{array}{c}\text { Iat } \\
\text { activity }\end{array}$ \\
\hline Wadi Horan & 3 & 1 & 1 & 1 & 3 & 2 & 1.8 & 2 & High \\
\hline WadiUbaiyidh & 3 & 1 & 1 & 1 & 3 & 3 & 2 & 3 & Moderate \\
\hline ShuiabHwaimy & 3 & 1 & 1 & 1 & 3 & 3 & 2 & 3 & Moderate \\
\hline ShuiabQusair & 3 & 1 & 2 & 1 & 3 & 3 & 2.1 & 3 & Moderate \\
\hline Main Basin & 3 & 1 & 2 & 1 & 3 & 2 & 2 & 3 & Moderate \\
\hline
\end{tabular}

As in figure (8). 


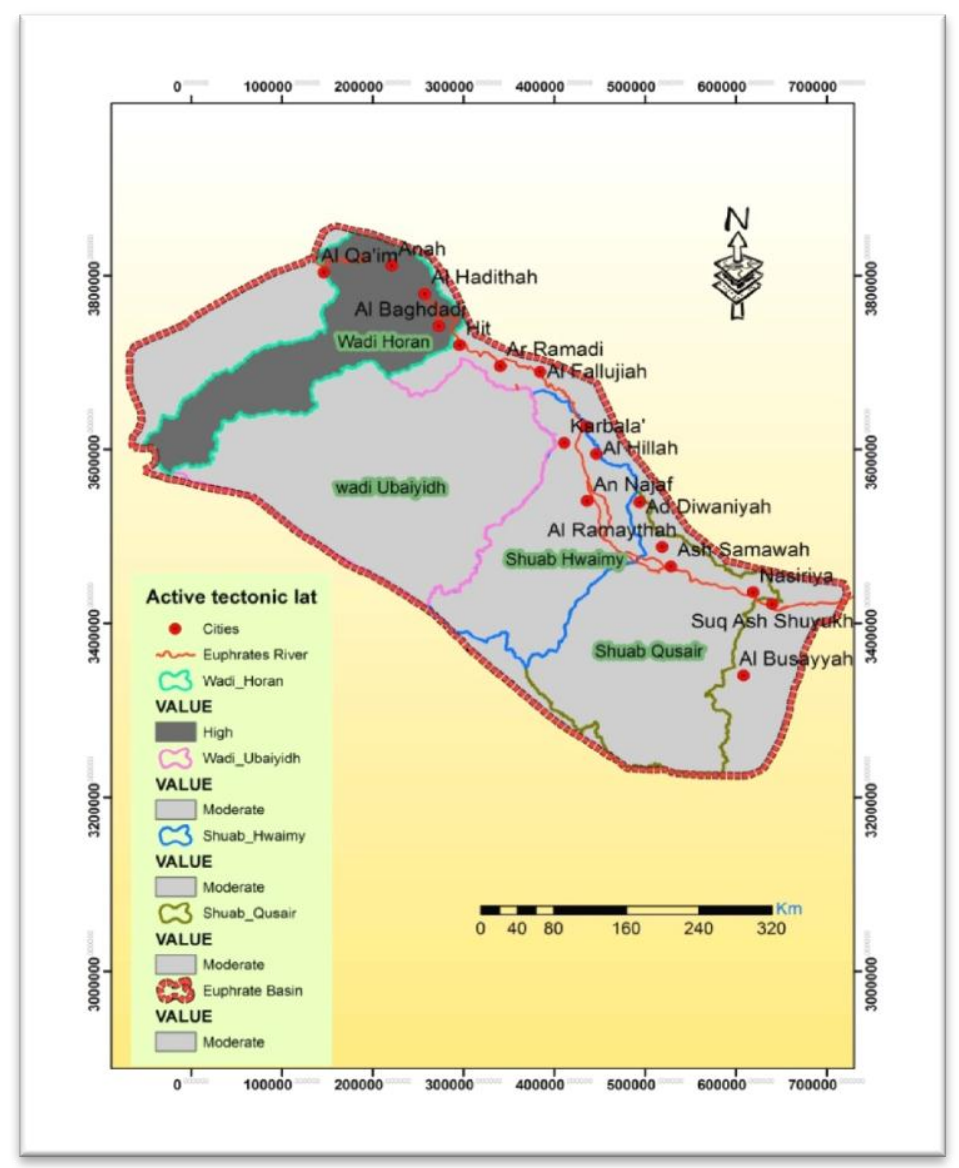

Figure (8) Shows the Iat Index

\section{Faults and Drainage network in study area}

The study area contains several sub-basins that lie in the western and southern of Iraq. These sub-basins were observed from the interpretation of using Digital elevation model processing, these basins have evolved as a result of plate movements, subsidence, uplift and various erosional processes.

The observation of Figure (7) shows different and variable relationship between faulting and valleys but most of the trends of faults are sub- parallel to Euphrates River. Faults orientations in the study area are parallel to NE-SW direction and NW-SE direction. Besides the type of drainage network in study area which is varied from dendritic to parallel with SW-NE trending and it's indicate that study area may be structurally control.

\section{Discussion \&Conclusion}

In present research, in view of geomorphic parameters the aspects of tectonic activities in Euphrates basin territory were discussed.

1. Seven indices were achieved as well as the basins characteristic as in table (1) so as to elicit tectonic efficiency for Euphrates basin.

2. Ten stream order recognized in study area for main basin (Euphrates basin) starts with tenth order and end with second order, Horan sub basin starts with ninth stream order and end with second order, Ubaiyidh sub basin starts with tenth order and end with second order, Shuab Hwaimy sub basin starts with tenth order and end with second order, Shuab Qusair starts with tenth order and end with second order.

3. With regard to the value of Drainage density (D) main basin and sub basins are in high classes which mean that the study area hasconsequence of slight or impermeable subsurface material, little vegetationas well as a good discharge for water and sediments. The Sinuosity index (S) of all study area are sinuous and its semi equilibrium. Hypsometric integral (HI) of Horan, Ubaiyidh and shuab Hwaimy sub basins shows high value of HI which means high rates of 
geological erosion while the shuab Qusair and main basin shows moderate of erosion rates, HI high valuesshows that study area is tectonic uplift. According to calculation of Drainage basin asymmetry (AF) the study area reflects inactive tectonic activity. TheBasin Shape (BS) all of basins are in third class and it exhibit inactive tectonic activity. Aftercompute Transverse Topographic Symmetry (T) parameter in the area under investigate, 10 isolated areas were estimated and the outcomedemonstrate that all sub basins lies in low active tectonics except wadi Horan and the main basin were moderate active tectonics. Basedon Active tectonic index (Iat) classification as in table (7) all the basins were moderate active tectonics except Horan sub basin is active tectonically.

4- Overall, intensity and tectonic vigor in different parts of the Euphrates basin and sub basinswere differentia, the results of morphotectonics parameters and the tectonic assessments demonstrate that study area considered as a modestlyvigor's territory as far as tectonic activity.

5- Different and variable relationship between faulting and valleys but most of the trends of faults are sub-parallel to Euphrates River. Faults orientations in the study area are parallel to NE-SW direction and NW-SE direction. Moreover the type of drainage network in study area which is varied from dendritic to parallel with SW-NE trending and it's indicate that study area may be structurally control.

\section{CONFLICT OF INTERESTS}

\section{There are no conflicts of interest.}

\section{References}

[1] M. Al-Jabare \& N. Al-Ansari. "The Hydrology. Published by ministry of higher education and scientific research". p,1063. 2000.

[2] G.M Lees, \& N.Falcon. The geographical history of Mesopotamian plian.Geogr.Journal.118 P. 1952.

[3] S. Z. Jassim \& J. C. Goff. Geology of Iraq, Dolin, 341p. 2006.

[4] Iraqi Bulletin of Geology and Mining. Geology of Iraqi Western Desert P, P 29- 50. 2007.

[5] A. N. Strahler. Quantitative geomorphology of drainage basins and channel networks. In Chow, V.T. (ed.) Handbook of Applied Hydrology, McGraw-Hill, New York. pp 439-476. 1964.

[6] K.Hironi. Land Use Planning and Geomorphology: A Study of SawaiMadhopur. Concept Publishing Company, 187 p. 1991.

[7] E.A. Keller \& P.Nicholas. Active Tectonic, Earthquakes, Uplift and Landscape. 2nd Edition, Prentice Hall, Upper Saddle River, 362 p. 1996.

[8]. L.B.Leopold \& M.G. Wolman \& J.P.Miller. Fluvial processes in geomorphology, W.H. Freeman \& Co., London. 1964.

[9] Morrish, Shawn, C.CHARACTERIZATION AND DIGITAL MORPHOTECTONIC ANALYSIS OF DRAINAGE BASINS IN A DEFORMING FOREARC, NICOYA PENINSULA, COSTA RICA. M.SC. Thesis, California State Polytechnic University, Pomona. P, 155. 2015.

[10]. R. El-Hamdouni, C.Irigraray, T.Fernandez, J. Chacon, and E.A. Keller. "Assessment of relative active tectonics, southwest border of Sierra Nevada, south Spain”. Geomorphology, Vol.96, P, P, 150-173. 2007.

[11]. Ahmad, Ansari Lari., Maryam, Ansari. Soraya, Ansari. 2016. Analysis Neotectonic Activities in Khafr Basin. Open Journal of Geology. 6, 484-497.P,P, 485-497. 2016.

[12] Sajadian, Mohammad,Reza, Mohsen Pourkermani1., ManochehrQorashi., andNaser,Hafezi,Moghaddas.. The Analysis of Transverse Topographic Symmetry Factor (T Index) in the Chekene-Mazavand, North East Iran. Open Journal of Geology. P, P 809-820. 2015. 


\section{التحليل المورموتكتونتك لحوض نهر الفرات/ العراق}

تم استخدام التحليل الموفولوجي والتحليل الموفوتكثونك للحصول على المعلومات التي تؤثر على الأحواض. تشمل منطقة الدراسة حوض نهر

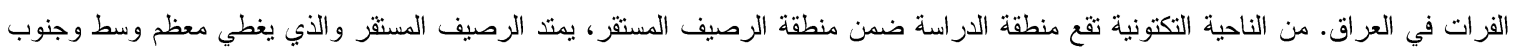

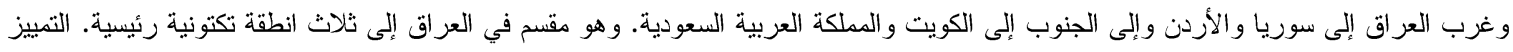
بين المؤشر ات المورفوتكتونك لحوض الفرات تم باستخدام سبعة مؤشرات. تم تقسيم حوض الفرات (الحوض الرئيسي) إلى أربعة أحواض فرعية (s.b)

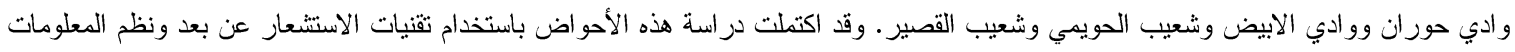

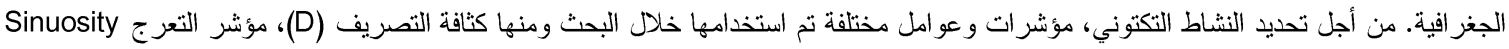

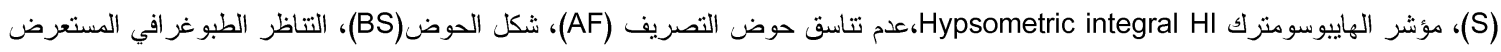

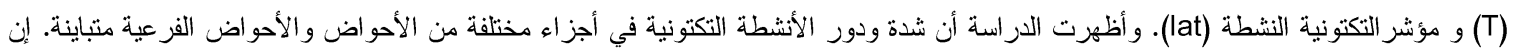

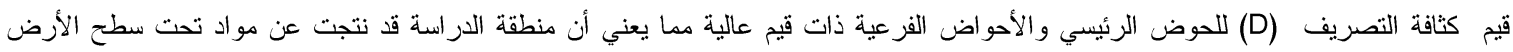
ضعيفة أو غير منفذة، ونباتات متفرقة بالإضافة إلى التصريف الجيد للمياه و الرواسب. مؤشر التعرج Sinuosity S لجميع منطقة الدراسة هي متعرجة

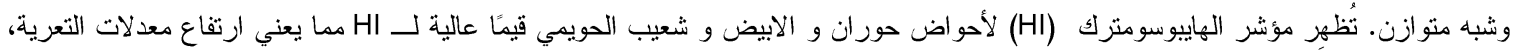

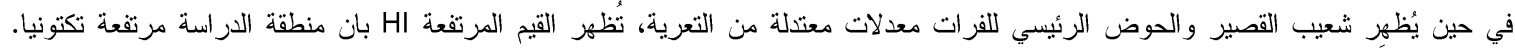

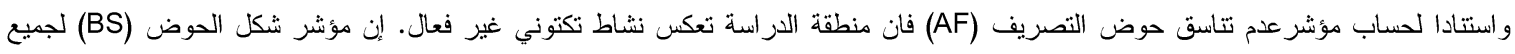

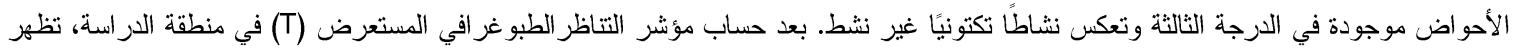

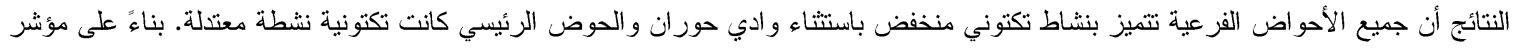

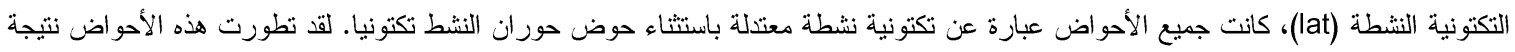

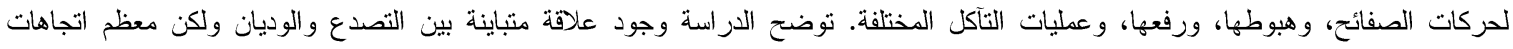
الصدوع تكون متو ازية مع نهر الفزات. تكون اتجاهات الصدوع في منطقة الدراسة موازية لاتجاه NE-SW و اتجاه NW-SE. تصريف الجريان في منطقة الدراسة التي تتغير من الثكل الثجيري الى الثكل المتوازي مع اتجاه SW-NE ونتير إلى أن منطقة الدراسة قد تكون مسيطر عليها العامل التركيبي (البنيوي). الكلمات الدالة: المورموتكتونك، الاحواض الثانوية، كثافة التصريف، معامل التعرج، معامل الهايبوسومترك، معامل تتاظر الحوض، شكل الحوض، معامل نتاظر الطوبوغر افي المستعرض، معامل التكتوني الفعال. 